\title{
Модовый интерферометр Маха-Цандера на основе утоньшенного волокна для измерения показателя преломления жидкости
}

\author{
В.А. Симонов $^{*}$, В.С. Терентьев \\ Институт автоматики и электрометрии СО РАН \\ *E-mail: SimonovVA@iae.sbras.ru
}

DOI: 10.31868/RFL2020.173-174

Интерферометр Маха-Цандера (ИМЦ), плечи которого образуют разные моды оптического волокна, могут использоваться в качестве датчиков уровня жидкости [1], показателя преломления и/или температуры/деформации/изгиба [2]. Разность длин плеч возникает из-за различия эффективного показателя преломления $n_{\text {eff }}$ для разных мод. К недостаткам можно отнести образование более чем двух плеч, что приводит к интерференции большего числа лучей, чем в случае классического ИМЦ, и усложняет анализ интерференционной картины.

Существует несколько технологически несложных способов создать ИМЦ такого типа: вставка из другого типа волокна [1]; вставка волокна со смещением оси [3]; неадиабатическое изменение диаметра волокна [4]; наклонные и длиннопериодные ВБР. Также, возможны комбинации вышеперечисленных способов. Анализ показаний датчиков различных величин (показателя преломления среды, температуры и деформации) обычно производится по смещению положения минимума или максимума интерференционной картины (одного или нескольких). Также для этого использовалась Фурье-фильтрация [5] и быстрое преобразование Фурье [6].

В данной работе предлагается способ, являющейся комбинацией нескольких из описанных и представленный на Рис.1(a). Преимуществами данного метода являются использование одного вида волокна и возможность тонкой настройки связи основной моды входного волокна с модами вставки за счет подбора степени утоньшения. Кроме того, предлагается использовать преобразование Фурье для анализа интерференционной картины ИМЦ, что позволит обойти ограничение, связанное со смещением экстремума интерференционной картины на величину, большую чем область свободной дисперсии интерферометра, а также снизить влияние интерференции с возбуждаемыми модами высшего порядка.
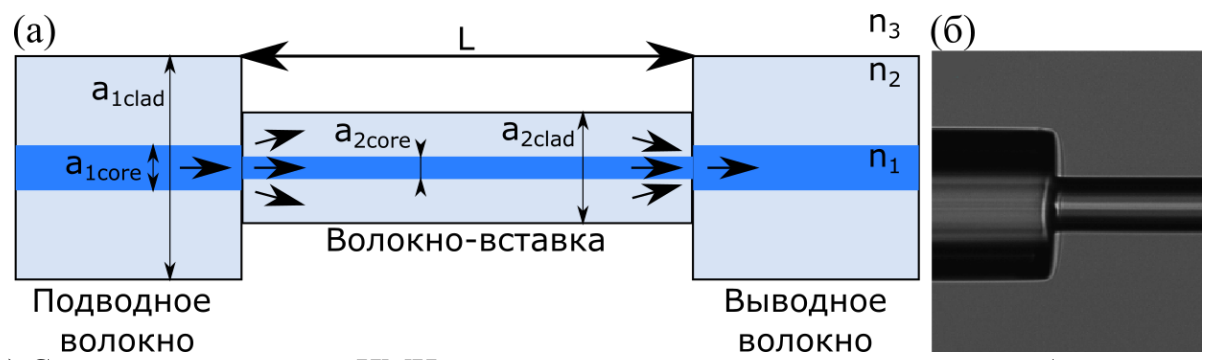

Рис. 1. (а) Схема предлагаемого ИМЦ: $\mathrm{a}_{1 \text { core }}$ и $\mathrm{a}_{1 \mathrm{clad}}-$ диаметры сердцевины и оболочки подводного и выводного волокон, $\mathrm{a}_{2 \text { core }}$ и $\mathrm{a}_{2 \mathrm{clad}}$ - диаметры сердцевины и оболочки утоньшенной вставки;

(б) изображение сварки подводного волокна с утоньшенной вставкой диаметром 44,5 мкм.

Для начала с помощью аналитической модели методом направляемых мод, числено реализованной на языке Fortran $[7,8]$, проведено моделирование параметров предложенного ИМЦ для поиска оптимальных степеней утоньшения волокна-вставки. Находились собственные (направляемые) моды используемых во- 
локон, коэффициенты связи между модами, причем для вставки необходимо было искать еще и моды оболочки. В месте первой сварки энергия основной моды распределяется между основной модой, модами оболочки волокна-вставки и вытекающими модами (потерями). С помощью моделирования определены оптимальные длина волокна и степень утоньшения с точки зрения видности спектральной интерференционной картины.

На второй сварке, отстоящей от первой на расстоянии L (Рис. 1(a)), также происходит перераспределение энергии мод, но уже только в одну направляемую моду сердцевины.

Был изготовлен образец из волокна марки SMF-28е+ с помощью сварочного аппарата Fujikura LZM-100 [9] на основе $\mathrm{CO}_{2}$-лазера. Отрезок волокна с изначальным диаметром оболочки 125 мкм утоньшался до диаметра 44,5 мкм (что соответствует $\mathrm{TR} \approx 2,8)$ и длины $\approx 50$ мм. Далее производилась вварка вставки, как показано на Рис. 1(б). Полученный образец имел длину L $\approx 32$ мм.

Для параметров изготовленного образца был рассчитан спектр пропускания для $\mathrm{n}_{3}=1$, а для экспериментального измерены спектры пропускания при двух окружающих средах: воздух и дистиллированная вода $\left(\mathrm{n}_{3}=1,3164\right)$ (Рис. 2(a)). Преобразование Фурье для этих спектров показано на Рис. 2(б), откуда видно хорошее совпадение эксперимента и расчета для основного порядка интерференции (число периодов 2,69 для экспериментального спектра и 2,72 для расчетного). Также видно, что основной порядок интерференции помещенного в воду образца ИМЦ существенно изменяется (до 2,47 периодов на диапазон). Таким образом, можно оценить чувствительность к показателю преломления среды в -0,69 ЕПП ${ }^{-1}$.
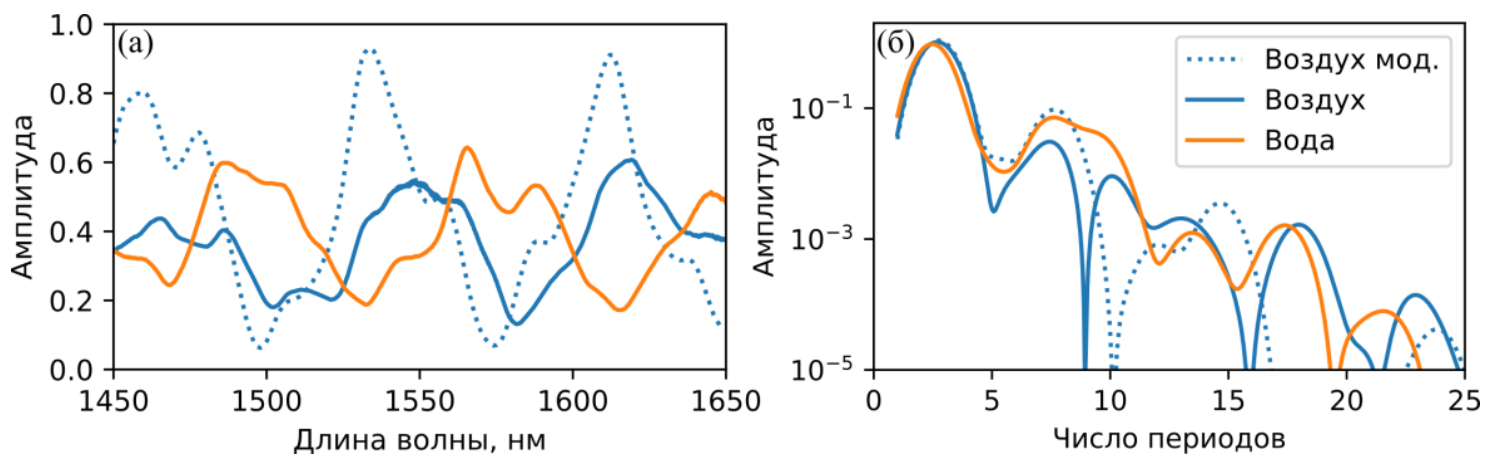

Рис. 2. (a) Расчетный спектр пропускания ИМЦ с $\mathrm{TR}=2,8$ и L=32 мм (синий пунктир) спектры пропускания изготовленного образца: на воздухе (синяя сплошная) и в дистиллированной воде (оранжевая); (б) результат Фурье-преобразования соответствующих спектров.

Работа выполнена в рамках темы госзадания ИАиЭ СО РАН (№ гос. рег. ААААА17-117062110026-3). Работа выполнена с использованием оборудования Центра коллективного пользования «Высокоразрешающая спектроскопия газов и конденсированных сред» ИАиЭ СО РАН.

\section{Литература}

[1] O.V. Ivanov, Opt. Fiber Technol., 55, 102146 (2020).

[2] S. Gao et al., Sensors Actuators B Chem., 188, 931-936 (2013).

[3] M.S. Avila-Garcia et al., Opt. Lasers Eng., 107, 202-206 (2018).

[4] X. Han et al., Sensors, 19, 5440 (2019).

[5] H.W. Fu et al., IEEE Photonics Technol. Lett., 27, 658-660 (2015).

[6] X. Yu et al., IEEE Photonics J., 8, 6801710 (2016).

[7] О.В. Иванов, С.А. Никитов, Ю.В. Гуляев, УФН, 176, 175-202 (2006).

[8] В.С. Терентьев, В.А. Симонов, Квантовая электроника, 46, 142-146 (2016).

[9] В.А. Симонов, Б.Б. Ульзутуев, ФОТОН-ЭКСПРЕСС, 158, 316-317 (2019). 